\title{
Reduced Graphene Oxide Supported Cobalt-Calcium Phosphate Composite for Electrochemical Water Oxidation
}

\author{
Keunyoung Lee ${ }^{1}$, Wonseok Yang ${ }^{2}$, Eunji Pyo ${ }^{1}$, Hyebin Choi ${ }^{1}$, Yeona Cha ${ }^{1}$, Seonhong Lee ${ }^{3}$, , Chung Soo Kim ${ }^{3}$, \\ Dong-Kwon Lim ${ }^{2, *}$ and Ki-Young Kwon ${ }^{1, *}$ \\ 1 Department of Chemistry, Gyeongsang National University, Jinju 52828, Korea; sofiato96@gnu.ac.kr (K.L.); \\ eunji2684@gnu.ac.kr (E.P.); gpqls3214@gnu.ac.kr (H.C.); yooona20@gnu.ac.kr (Y.C.) \\ 2 KU-KIST Graduate School of Converging Science and Technology, Korea University, Seoul 02841, Korea; \\ wowbluesky@korea.ac.kr \\ 3 Analysis \& Certification Center, Korea Institute of Ceramic Engineering \& Technology, Jinju 52851, Korea; \\ sh0381@kicet.re.kr (S.L.); cskim@kicet.re.kr (C.S.K.) \\ * Correspondence: dklim@korea.ac.kr (D.-K.L.); kykwon@gnu.ac.kr (K.-Y.K.); \\ Tel.: +82-2-3290-4611 (D.-K.L.); +82-55-772-1493 (K.-Y.K.)
}

Citation: Lee, K.; Yang, W.; Pyo, E.; Choi, H.; Cha, Y.; Lee, S.; Kim, C.S.; Lim, D.-K.; Kwon, K.-Y. Reduced Graphene Oxide Supported Cobalt-Calcium Phosphate Composite for Electrochemical Water Oxidation. Catalysts 2021, 11, 960. https:// doi.org/10.3390/ catal11080960

Academic Editor: Enric Brillas

Received: 14 July 2021

Accepted: 10 August 2021

Published: 11 August 2021

Publisher's Note: MDPI stays neutral with regard to jurisdictional claims in published maps and institutional affiliations.

Copyright: (c) 2021 by the authors. Licensee MDPI, Basel, Switzerland. This article is an open access article distributed under the terms and conditions of the Creative Commons Attribution (CC BY) license (https:/ / creativecommons.org/licenses/by/ $4.0 /)$.

\begin{abstract}
We report the oxygen evolution reaction (OER) catalyst composed of cobalt-calcium phosphate on reduced graphene oxide $(\mathrm{CoCaP} / \mathrm{rGO})$. Our catalyst is prepared by the anodic electrolysis of calcium phosphate/rGO mixture loaded on indium-tin-oxide (ITO) in $\mathrm{Co}^{2+}$ aqueous solution. TEM, XPS and XRD experiments confirm that the crystal phase of calcium phosphate (CaP) is transferred into an amorphous phase of calcium oxide with phosphate (5.06 at \%) after anodic electrolysis. Additionally, the main cation component of calcium is replaced by cobalt ion. The current-voltage characteristics of $\mathrm{CoCaP} / \mathrm{rGO}$ showed a shoulder peak at $1.10 \mathrm{~V}$ vs. NHE, which originated from $\mathrm{Co}^{2+}$ to higher oxidation states $\left(\mathrm{Co}^{3+}\right.$ or $\left.\mathrm{Co}^{4+}\right)$ and a strong wave from water oxidation higher $+1.16 \mathrm{~V}$ vs. NHE at neutral condition ( $\mathrm{pH} 7$ ). CoCaP and $\mathrm{CoCaP} / \mathrm{rGO}$ showed 4.8 and $10 \mathrm{~mA} / \mathrm{cm}^{2}$ at $0.47 \mathrm{~V}$ of overpotential, respectively. The enhanced OER catalytic activity of $\mathrm{CoCaP} / \mathrm{rGO}$ arises from the synergetic interaction between the amorphous phase of $\mathrm{CoCaP}$ and electric conducting graphene sheets.
\end{abstract}

Keywords: OER; calcium phosphate; graphene

\section{Introduction}

As the demand for sustainable energy increases, much research has been conducted on the development of renewable and environmentally benign energy [1]. In regard to solar energy conversion into chemical energy, water splitting has been extensively investigated for last three decades. Especially, electrochemical catalysts that enable the water oxidation have been considered as critical factor to improving the energy conversion efficiency. So far, precious metals or precious metals oxides (e.g., $\mathrm{Ru} / \mathrm{Ir}$ oxides) are regarded as the prototype of oxygen evolution reaction (OER) catalysts [2-6]. However, these precious metals cannot be generally used because of their high cost $[7,8]$. Therefore, it is necessary to develop alternative catalysts that are made of relatively low-cost and earth-abundant elements with catalytic activity and durability. Hence, comparatively inexpensive transition metals (cobalt [9-11], copper [12], iron [13,14], etc.) deposited on carbon-based substrates graphene [15-17] and carbon nanotubes [18-20]) have been widely investigated. Generally, transition metal oxide/phosphates have insufficient electrical conductivity and a low surface area, which result in sluggish kinetics during the OER. Meanwhile, graphene oxide (GO) based materials have been widely used for oxygen/hydrogen evolution reaction and oxygen reduction reaction (ORR) because of their atomic thinness and high electrical conductivity after the reduction treatment [21-24]. For example, $\mathrm{Co}_{3} \mathrm{O}_{4}$ nanoparticles reduced graphene oxide (rGO) [25], cobalt oxide on crumpled graphene with a high surface 
area [26], iron and nickel on $\mathrm{GO}$ [27], solvothermal synthesis of $\mathrm{NiCo}_{2} \mathrm{~S}_{4}$ nanoparticles on rGO [28] and GO-incorporated Cu-MOF composite [29] were utilized for HER, OER and ORR catalysts. The Nocera group demonstrated that an amorphous cobalt oxide containing phosphate group (so called Co-Pi) exhibited excellent OER catalytic properties under neutral $\mathrm{pH}$ conditions [30-36]. This Co-Pi has been successfully prepared on various substrates by in situ anodic electrolysis in phosphate buffer containing a small number of cobalt ions [31,37]. Previously, we developed a noble preparation method for the cobalt phosphate catalyst [38]. Particularly, we utilized the solid phase of hydroxyapatite (HAP) as a phosphate source instead of a solution phase of phosphate buffer. Our catalysts were prepared by the ion-exchange reaction of HAP (CoHAP) with aqueous cobalt ions solution [39]. Here, we developed the $\mathrm{CoCaP} / \mathrm{rGO}$ OER catalyst through the anodic electrolysis of calcium phosphate and graphene mixture loaded on ITO under aqueous $\mathrm{Co}^{2+}$ solution. After the anodic electrolysis, the calcium phosphate crystallites are changed into an amorphous cobalt oxide/phosphate. In addition, these cobalt oxide/phosphates are well dispersed in $\mathrm{rGO}$ without aggregation. Therefore, $\mathrm{CoCaP} / \mathrm{rGO}$ exhibits enhanced OER catalytic activity compared to $\mathrm{CoCaP}(\mathrm{CoCaP} / \mathrm{rGO}$ requires only $457 \mathrm{mV}$ to drive $10 \mathrm{~mA}$ ). Furthermore, the Tafel slope was improved after the incorporation of $\mathrm{Co}^{2+}$ ions (239 $\mathrm{mV} /$ dec to $132 \mathrm{mV} / \mathrm{dec}$ ).

\section{Results}

$\mathrm{CoCaP} / \mathrm{rGO}$ is synthesized in two steps. First, $\mathrm{CaP} / \mathrm{rGO}$ is prepared by the precipitation from the mixture of aqueous solution containing $\mathrm{rGO}, \mathrm{Ca}^{2+}$ and $\mathrm{HPO}_{4}{ }^{-}$. The ink of $\mathrm{CaP} / \mathrm{rGO}$ is loaded onto the ITO substrate. Second, $\mathrm{CaP} / \mathrm{rGO}$ is electrochemically converted into $\mathrm{CoCaP} / \mathrm{rGO}$ by anodic electrolysis in the $\mathrm{Co}^{2+}$ aqueous solution.

Figure 1a shows the grayish color of $\mathrm{CaP} / \mathrm{rGO}$ on ITO. Calcium phosphate and rGO are white and black colored, respectively. The mixture loaded on an ITO exhibits a gray color. After the anodic electrolysis of $\mathrm{CaP} / \mathrm{rGO}$ in the $\mathrm{Co}^{2+}$ aqueous solution for $60 \mathrm{~min}$, the gray color of $\mathrm{CaP} / \mathrm{rGO}$ is changed into a dark brown (Figure 1b, Supplementary Video S1). The dark brown color was previously reported in the OER catalyst based on Co-Pi [40-42]. Figure 1c represents the current density profile during anodic electrolysis. The current density is the highest at $5 \mathrm{~min}$ and gradually decreases, then reaches the baseline level after $20 \mathrm{~min}$. These currents seem to be caused by the charge transfer involved in the $\mathrm{CoCaP} / \mathrm{rGO}$ formation, not by the faradaic current of water oxidation. $\mathrm{CoCaP} / \mathrm{rGO}$ is precipitated on ITO by the reaction between the phosphate group of calcium phosphate and the $\mathrm{Co}^{2+}$ in aqueous solution, in which $\mathrm{Co}^{2+}$ is changed into $\mathrm{Co}^{3+} / \mathrm{Co}^{4+}$ given bias $(+1.3 \mathrm{~V}$ vs. NHE). The total charge flow for $60 \mathrm{~min}$ is $150 \mathrm{mC} / \mathrm{cm}^{2}$. For the control experiment, the current density profile of the bare ITO electrode without $\mathrm{CaP} / \mathrm{rGO}$ is carried out under the same electrolysis condition (Figure 1c). In this case, the current is barely flowed and the color of the ITO is light yellow (Supplementary Figure S1), which is obviously different from the dark brown color of $\mathrm{CoCaP} / \mathrm{rGO}$ film. Figure $1 \mathrm{~d}$ shows the change of XRD patterns before and after anodic electrolysis. The calcium phosphate from the reaction of calcium nitrate and sodium phosphate dibasic is well matched with monetite $\left(\mathrm{CaHPO}_{4}\right.$, JCPDS No. 70-1425, marked with red dots) patterns. The average crystal size of CaP is $33.9 \mathrm{~nm}$ based on a calculation by the Scherrer equation (Supplementary Figure S2). After anodic electrolysis, the diffraction patterns of the monetite disappeared. In addition, no new diffraction patterns are observed. Therefore, we interpret that the monetite crystallite is changed into an amorphous form of cobalt/oxides in which the amorphous morphology of cobalt phosphate improves OER activity in the previous report [43,44]. 

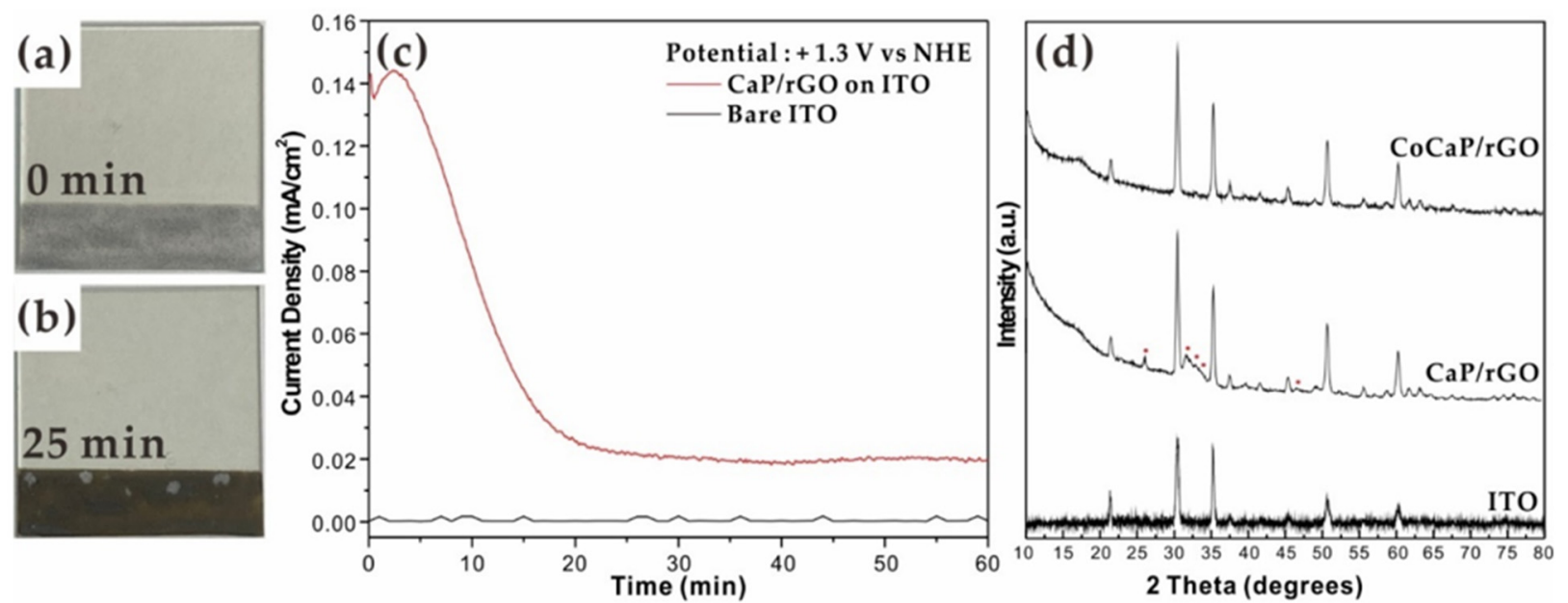

Figure 1. Photographs of (a) $\mathrm{CaP} / \mathrm{rGO}$ and (b) $\mathrm{CoCaP} / \mathrm{rGO}$ film on ITO after anodic electrolysis for $25 \mathrm{~min}$. (c) Current density for anodic electrolysis at $+1.3 \mathrm{~V}$ vs. NHE in $20 \mathrm{mM} \mathrm{Co}^{2+}$. (d) XRD patterns of $\mathrm{CaP} / \mathrm{rGO}, \mathrm{CoCaP} / \mathrm{rGO}$ loaded on ITO electrode, $\mathrm{CaHPO}_{4}$ (monetite) and ITO electrode.

TEM and EDS elemental mappings are performed to investigate the morphology and local/surface elemental distribution of $\mathrm{CaP} / \mathrm{rGO}$ and $\mathrm{CoCaP} / \mathrm{rGO}$. CaP/rGO (Supplementary Figure S3) shows elongated shape of about $40.1 \mathrm{~nm}$ in width and $97.3 \mathrm{~nm}$ in length, on average. Previously, we investigated the impact of $\mathrm{pH}$ on the morphology of calcium phosphate in which monetite with an elongated shape is formed when the base is not added, as in this study [45]. CoCaP/rGO composite (Figure 2a,b), on the other hand, does not exhibit a distinct shape. These features are similarly observed in SEM images (Supplementary Figure S3). Therefore, we concluded that the anodic electrolysis is accompanied by the absence of diffraction patterns of monetite and morphology changes (Figure 1d, Figure 2 and Supplementary Figure S2). In addition, TEM-EDS mapping measurements (Figure 2c-i) show that all chemical species, especially cobalt ions, are evenly distributed in the entire sample of $\mathrm{CoCaP} / \mathrm{rGO}$ without local aggregation. TEM-EDS analysis indicates that after the anodic electrolysis in the $\mathrm{Co}^{2+}$ aqueous solution, the atomical composition of $\mathrm{Ca}^{2+}$ decreased from 12.24 at $\%$ to 0.48 at $\%$. Meanwhile, those of $\mathrm{Co}^{2+}$ increased by $3.61 \mathrm{at} \%$. The main cation of calcium ion is replaced by the cobalt ion after the anodic electrolysis. According to SEM images, the elongated crystallites of $\mathrm{CaP} / \mathrm{rGO}$ cannot be distinguishable after the anodic electrolysis for an hour. The SEM-EDS elemental mapping measurements showed consistent results with the TEM-EDS experiments. The surface composition of the samples is analyzed by an X-ray photoelectron spectrum (XPS). The survey spectrum (Figure $3 \mathrm{a}$ ) of the $\mathrm{CaP} / \mathrm{rGO}$ and $\mathrm{CoCaP} / \mathrm{rGO}$ confirms the presence of the carbon, calcium, oxygen, phosphorous and cobalt. While the $\mathrm{Ca} 2 \mathrm{~s}$ and $2 \mathrm{p}$ peak of $\mathrm{CaP} / \mathrm{rGO}$ almost disappeared after the anodic electrolysis, an additional new peak of Co $2 \mathrm{p}$ is observable. Based on the quantitative analysis by XPS, the atomic percentage of calcium is estimated as $6.54 \%$ for the $\mathrm{CaP} / \mathrm{rGO}$ composite. After the anodic electrolysis, the atomic percentages of calcium decreased by $0.05 \%$, while the cobalt species was $1.8 \%$. The trend change of the elemental change is consistent with TEM-EDS (Figure 2c-2i). Therefore, we confirm that the main cation of composite changed from calcium to cobalt after the anodic electrolysis. High resolution Co $2 \mathrm{p}$ XPS spectra show $2 \mathrm{p}_{3 / 2}$ and $2 \mathrm{p}_{1 / 2}$ peaks for cobalt at 780.95 and $795.18 \mathrm{eV}$ [46]. Co species is considered to be mainly in the 2+ oxidation state. Additionally, the $\mathrm{Co} 2 \mathrm{p}_{3 / 2}$ with a shoulder peak indicates that $\mathrm{CoCaP} / \mathrm{rGO}$ may contain cobalt cations in the form of both $\mathrm{Co}^{2+}$ and $\mathrm{Co}^{3+}$ cations [37,47]. Supplementary Figure S4 represents that a phosphorous $2 \mathrm{p}$ peak at $132.78 \mathrm{eV}$ indicates the existence of phosphate in $\mathrm{CoCaP} / \mathrm{rGO}[48,49]$. 


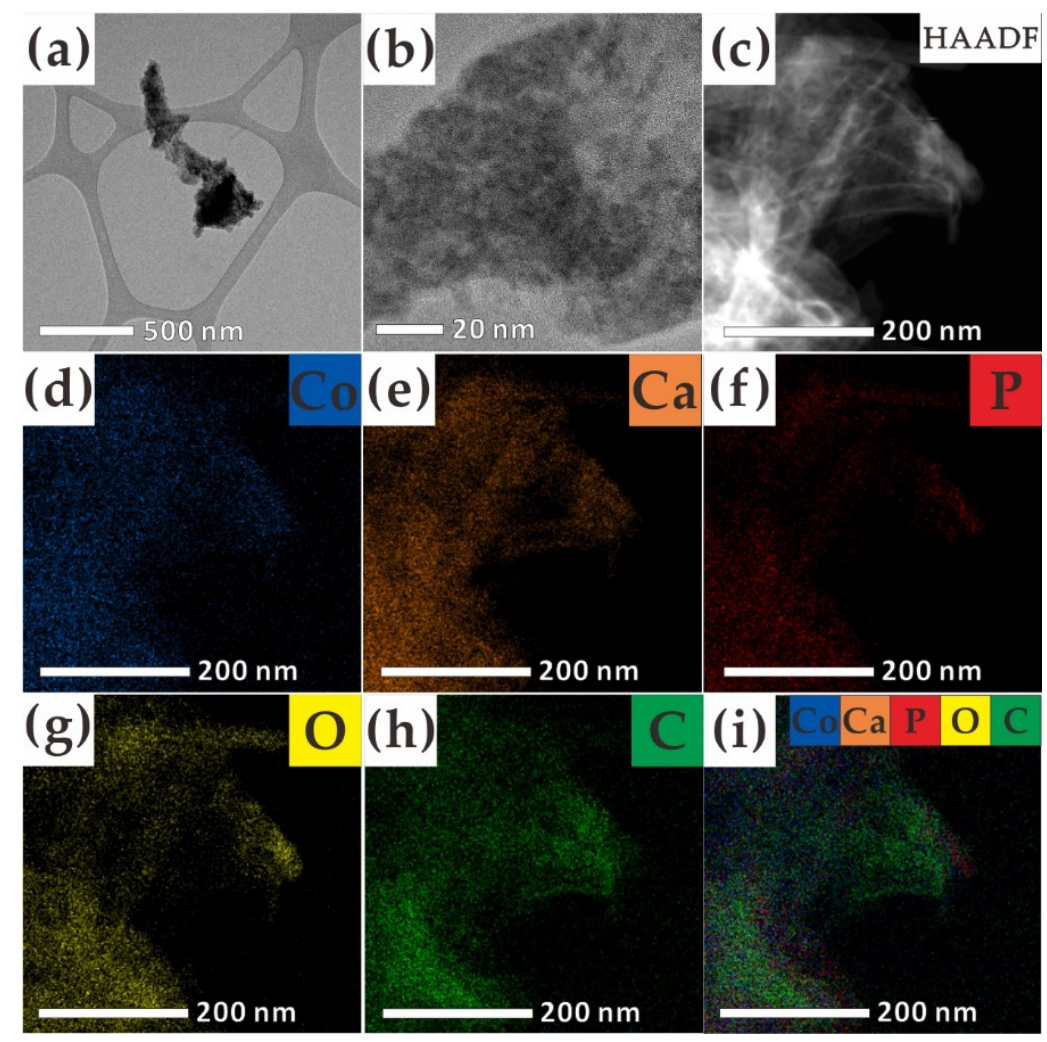

Figure 2. TEM images of (a) $\mathrm{CoCaP} / \mathrm{rGO}$, (b) a high resolution TEM image of $\mathrm{CoCaP} / \mathrm{rGO}$ and EDS elements mapping of CoCaP/rGO, (c) a TEM image, (d) Co, (e) Ca, (f) $\mathrm{P},(\mathbf{g}) \mathrm{O}$, (h) $\mathrm{C}$ and (i) an overlapping of $\mathrm{Co}, \mathrm{Ca}, \mathrm{P}, \mathrm{O}, \mathrm{C}$.
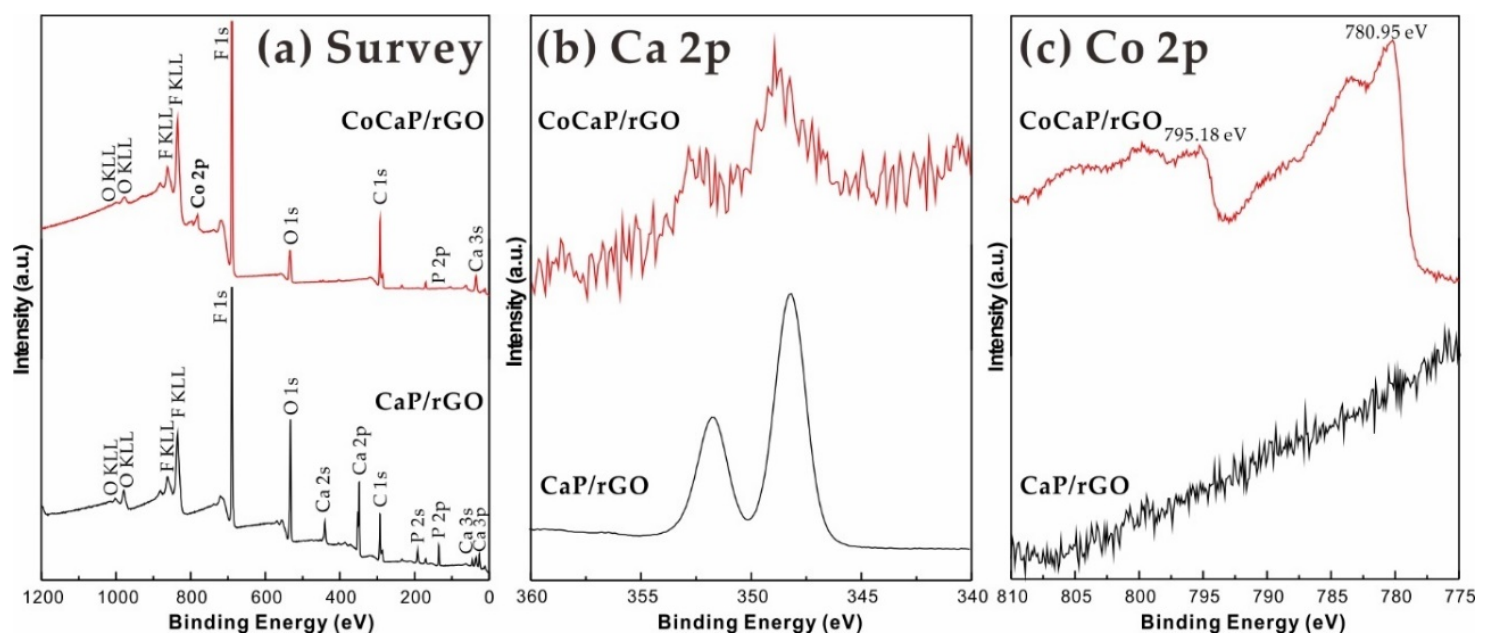

Figure 3. XPS spectrum of (a) Survey, (b) $\mathrm{Ca} 2 \mathrm{p}$ and (c) $\mathrm{Co} 2 \mathrm{p}$ of $\mathrm{CaP} / \mathrm{rGO}$ and $\mathrm{CoCaP} / \mathrm{rGO}$. (Fluorine signal originated from Nafion.)

The electrochemical characterizations (cyclic voltammetry (CV), linear sweep voltammetry (LSV) and bulk electrolysis) of $\mathrm{CoCaP}$ and $\mathrm{CoCaP} / \mathrm{rGO}$ are performed by commercial potentiostat with three electrode system under neutral $\mathrm{pH}$ conditions $(0.1 \mathrm{M} \mathrm{KPi}, \mathrm{pH}$ 7). Details are described in the experimental method. Figure 4a shows the cyclic voltammetry of $\mathrm{CaP}$ and $\mathrm{CoCaP} / \mathrm{rGO}$ on a glassy carbon electrode $(5 \mathrm{~mm}$ diameter). The oxidative wave at $+1.1 \mathrm{~V}$ vs. NHE is observed from both the CV and LSV curves of CoCaP/rGO (Figure $4 \mathrm{a}, \mathrm{b}$ ). This shoulder is commonly observed in Co-Pi catalysts and originated from the $\mathrm{Co}^{2+} / \mathrm{Co}^{3+}$ or $\mathrm{Co}^{4+}$ transitions $[33,35,37,50-52]$. Figure $4 \mathrm{~b}$ presents LSV curves with a sweep rate of $5 \mathrm{mV} / \mathrm{s}$ in $0.1 \mathrm{M} \mathrm{KPi}(\mathrm{pH} 7)$. The current densities of $\mathrm{CoCaP}$ and $\mathrm{CoCaP} / \mathrm{rGO}$ 
exhibit $3.5 \mathrm{~mA} / \mathrm{cm}^{2}$ and $15 \mathrm{~mA} / \mathrm{cm}^{2}$ at $1.3 \mathrm{~V}$ vs. NHE, respectively. Due to their low electric conductivity, transition metal oxide/phosphates combined with rGO and CoCaP significantly induces the improvement of OER catalytic activity. The improvements of ORR and HER catalytic activity are additionally reported by the hybrid of the catalyst and GO [53-55]. Previously, we reported that cobalt incorporated hydroxyapatite (CoHAP) OER catalyst. CoCaP/rGO showed approximately ten-fold higher OER activity than CoHAP $\left(1.2 \mathrm{~mA} / \mathrm{cm}^{2}\right.$ at $1.3 \mathrm{~V}$ vs. NHE). CoHAP is prepared by the ion exchange reaction of HAP by the simple immersion of $\mathrm{HAP}$ in aqueous $\mathrm{Co}^{2+}$ solution, in which cobalt ions are coated on the surface of HAP. Therefore, the number of cobalt species in CoHAP is much less than that of cobalt species in $\mathrm{CoCaP} / \mathrm{rGO}$ prepared by anodic electrolysis. The electrochemical active surface area of both samples is determined by measuring double-layer capacitance using CV at different scan rates $(20,30,50,100$ and $200 \mathrm{mV} / \mathrm{s}$ ) in the potential region having no Faradaic current (Figure 4c and Figure S6). The capacitance of $\mathrm{CoCaP} / \mathrm{rGO}$ is approximately eleven-fold over that of $\mathrm{CoCaP}$. Therefore, the increased catalytic active area by the dispersion of CoCaP on rGO surface enhances OER catalytic activity. Figure 4d and Supplementary Movie S2 illustrate a stability of CoCaP and $\mathrm{CoCaP} / \mathrm{rGO}$ loaded on ITO as a working electrode at the overpotential of $680 \mathrm{mV}$ through the bulk electrolysis over $24 \mathrm{~h}$. Both $\mathrm{CoCaP} / \mathrm{rGO}$ and $\mathrm{CoCaP}$ present durability with $90 \%$ and $95 \%$ after the potential is applied. The electrocatalytic properties of both $\mathrm{CaP} / \mathrm{rGO}$ and $\mathrm{CoCaP} / \mathrm{rGO}$ composite (Figure 4e) are estimated by Tafel plots and showed linearity in the range of ca. $100 \mathrm{mV}$ of overpotentials. The Tafel slope for $\mathrm{CoCaP} / \mathrm{rGO}$ shows an improved activity with a slope of $132 \mathrm{mV} /$ dec compared to the that of CoCaP (239 mV/dec). This lower value is comparable to other Tafel slopes of cobalt based OER catalysts performed under $\mathrm{pH} 7$ conditions (166 mV/dec for Co-Bi nanoarray [56], $121 \mathrm{mV} / \mathrm{dec}$ for $\mathrm{CoFe}(\mathrm{CN})_{5^{-}}$ PVP [57], 89 95 mV/dec for Co/Fe PBAs [58] and $137 \mathrm{mV} / \mathrm{dec}$ for CoO/CoSe 2 hybrid [59] electrocatalysts). The improved OER activity and Tafel slope of $\mathrm{CoCaP} / \mathrm{rGO}$ seem to originate from the efficient charge transfer from rGO to active catalytic species due to the well dispersion of $\mathrm{CoCaP}$ on rGO. Generally, transition metal oxide or phosphates exhibit poor electric conductivity. Therefore, combining active catalytic species with carbon supports has been widely applied in catalytic system of OER or ORR. For example, NiCo double hydroxide on $\mathrm{N}$-doped graphene [60], $\mathrm{CoFe}_{2} \mathrm{O}_{4}$ on graphene [61] and graphene- $\mathrm{Co}_{3} \mathrm{O}_{4}$ nanocomposite [62] were demonstrated for OER catalysts with higher OER/ORR activities and material durability. In addition to the charge transfer issue, the dispersion of CoCaP on rGO may provide more exposed catalytic active sites and a higher rate of mass transfer, which has been proven in carbon supports catalytic systems in previous reports [54,63-65].
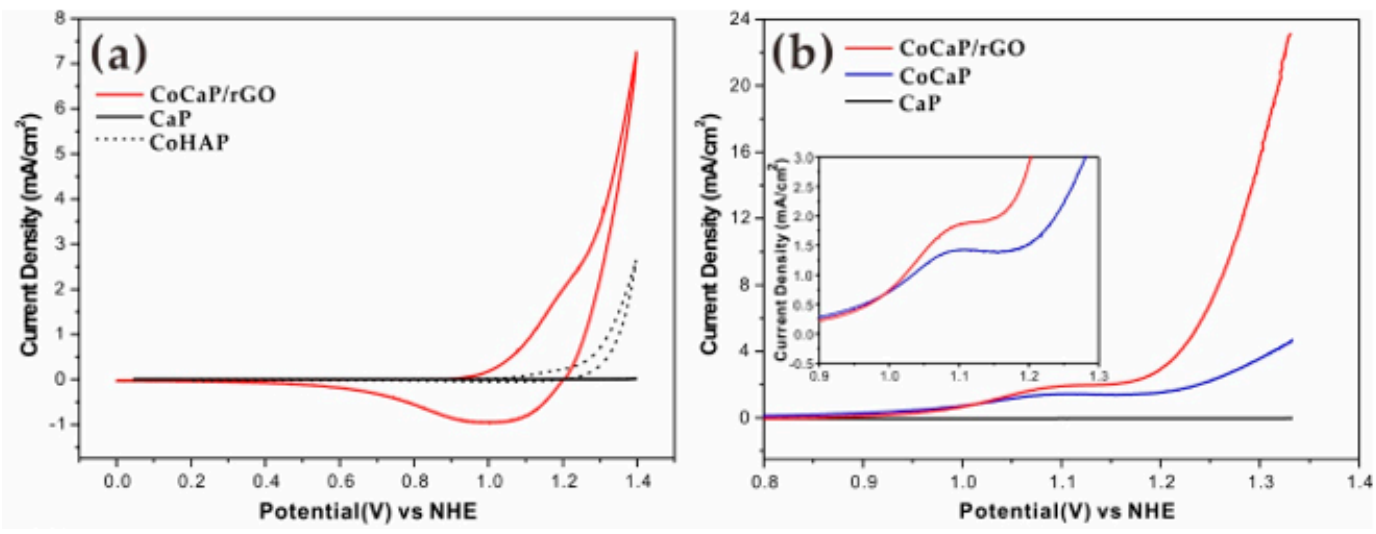

Figure 4. Cont. 

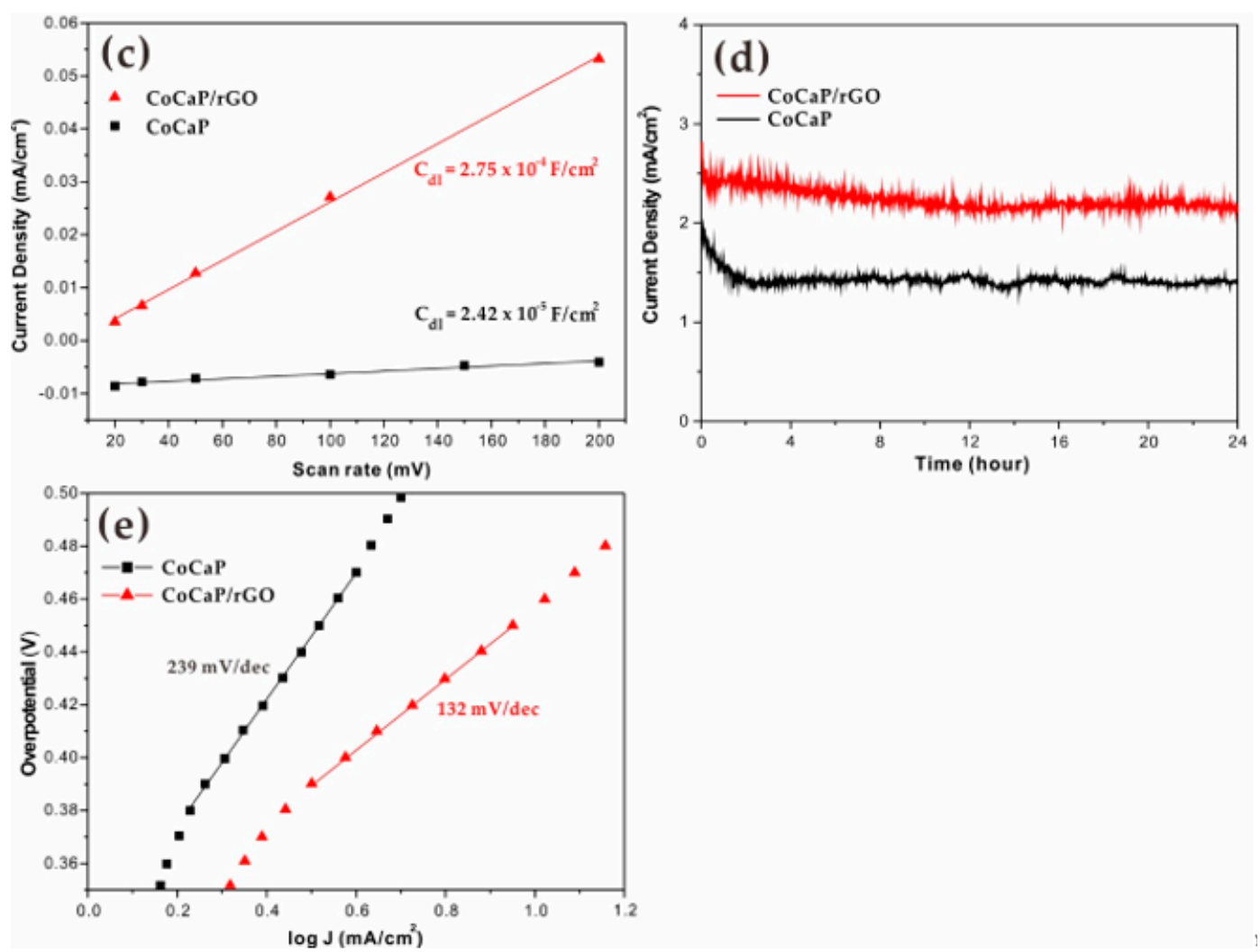

Figure 4. Electrochemical OER activities of $\mathrm{CoCaP} / \mathrm{rGO}$ composites. (a) Cyclic voltammetry in $0.1 \mathrm{M}$ KPi buffer solution (pH 7), (b) LSV curves, (c) current density versus various scan rates, (d) bulk electrolysis of CoCaP/rGO on an ITO electrode at $1.5 \mathrm{~V}$ vs. NHE for $24 \mathrm{~h}$ in $0.1 \mathrm{M} \mathrm{KPi}$ buffer $(\mathrm{pH} 7)$ and (e) Tafel plots of CoCaP and CoCaP/rGO.

\section{Materials and Methods}

\subsection{Materials}

$\mathrm{Ca}\left(\mathrm{NO}_{3}\right)_{2} \cdot 4 \mathrm{H}_{2} \mathrm{O}$ (Duksan Chemicals, Ansan, Korea), $\mathrm{Na}_{2} \mathrm{HPO}_{4}$ (99.0\%, Samchun Chemicals, Seoul, Korea), $\mathrm{Co}\left(\mathrm{NO}_{3}\right)_{2} \cdot 6 \mathrm{H}_{2} \mathrm{O}$ (Daejung chemicals, Siheung, Korea), $\mathrm{K}_{2} \mathrm{HPO}_{4}$ (Sigma Aldrich, $>98 \%$, Saint. Louis, MO, USA), $\mathrm{KH}_{2} \mathrm{PO}_{4}$ (Sigma Aldrich, St. Louis, MO, USA) and Nafion 117 containing solution (Sigma Aldrich, $\sim 5 \mathrm{wt} \%$ in a mixture of lower aliphatic alcohols and water, Saint. Louis, MO, USA) are purchased and used without purification.

\subsection{Preparation of Reduced Graphene Oxide ( $r G O)$}

The slightly modified Hummer's method was used to prepare graphene oxide (GO) [66]. $750 \mathrm{mg}$ of graphite flakes were mixed with a 9:1 mixture of $\mathrm{H}_{2} \mathrm{SO}_{4} / \mathrm{H}_{3} \mathrm{PO}_{4}(90: 10 \mathrm{~mL})$ and stirred in an ice bath. Then, $4.5 \mathrm{~g}$ of potassium permanganate was added very slowly to the reaction mixture by maintaining the temperature at $35-40{ }^{\circ} \mathrm{C}$. The reaction mixture was stirred at $50-55^{\circ} \mathrm{C}$ for $12 \mathrm{~h}$ and then cooled to room temperature, followed by the addition of $100 \mathrm{~mL}$ of iced water containing $30 \% \mathrm{H}_{2} \mathrm{O}_{2}$ [67-69]. The resulting solution was centrifuged at $8000 \mathrm{rpm}$ for $30 \mathrm{~min}$ and the supernatant was removed. The gel-like product was washed 5-6 times with $50 \mathrm{~mL}$ of distilled water. GO powder was obtained by dialysis with the membrane for 3 days to remove acid in the product completely, followed by lyophilization for 3 days. A total of $250 \mathrm{mg}$ of as-obtained GO powder were dispersed in $250 \mathrm{~mL}$ of DI water; then, the $\mathrm{pH}$ of the solution was adjusted to 10.0-11.0 by adding a trace amount of ammonium hydroxide solution $(28 \%, w / w)$. A total of $1.25 \mathrm{~mL}$ of hydrazine hydrate were added to the solution and stirred at $95^{\circ} \mathrm{C}$ for $1 \mathrm{~h}$. The solution color became slightly darker as the reaction progressed [67-69]. The reaction mixture was centrifuged at $12,000 \mathrm{rpm}$ for $30 \mathrm{~min}$, then washed with DI water. Finally, the rGO dispersion was lyophilized to obtain rGO powder. 


\subsection{Preparation of Catalyst}

Calcium phosphate [70] reduced graphene oxide $(\mathrm{CaP} / \mathrm{rGO})$ composite was prepared by the precipitation method. $20 \mathrm{mg}$ of rGO powder were dispersed in $10 \mathrm{~mL}$ of DI water by ultrasonication for $1 \mathrm{~h} .750 \mu \mathrm{L}$ of calcium nitrate tetrahydrate $(0.656 \mathrm{M})$ were added into $10 \mathrm{~mL}$ of the rGO suspension, followed by addition of $750 \mu \mathrm{L}$ of sodium phosphate dibasic $(0.394 \mathrm{M})$ solution. The reaction mixture was aged at $75^{\circ} \mathrm{C}$ for $24 \mathrm{~h}$. Finally, the CaP/rGO composite was obtained by washing using DI water for three times with centrifugation. The composite was lyophilized for $24 \mathrm{~h}$. CaP was obtained by the same steps as preparing $\mathrm{CoCaP} / \mathrm{rGO}$ without adding any rGO powder in the first step.

\subsection{Preparation of Working Electrode}

The glassy carbon electrode ( $5 \mathrm{~mm}$ in diameter) was cleaned with polishing using $1 \mu \mathrm{m}$ and $0.05 \mu \mathrm{m}$ alumina, followed by the sonication $3 \times 30 \mathrm{~s}$ in DI water. The Indium Tin Oxide (ITO) electrode was cleaned by the sonication $3 \times 30 \mathrm{~s}$ in DI water and acetone for two times, respectively. A total of $5 \mathrm{mg}$ of as-obtained CaP/rGO composite were added into $150 \mu \mathrm{L}$ of ethanol and $80 \mu \mathrm{L}$ of $5 \%$ Nafion 117 solution [71]. This ink was ultrasonicated for $30 \mathrm{~min}$. A total of $2.0 \mu \mathrm{L}$ and $10 \mu \mathrm{L}$ of ink were loaded onto glassy the carbon electrode $\left(0.197 \mathrm{~cm}^{2}\right.$ ) and ITO electrode (area: $2 \mathrm{~cm} \times 0.5 \mathrm{~cm}$ ) individually, then dried at ambient conditions.

\subsection{In Situ Preparation of Cobalt Calcium Phosphate/rGO Composite (CoCaP/rGO)}

The CoCaP/rGO was prepared by in situ anodic electrolysis. The electrolysis was done with a three-electrode electrochemical cell system using commercial potentiostat (EC Epsilon, BASi and ZIVE SP1, Wonatech). CaP/rGO on GCE (or ITO), Ag/ AgCl and Pt-wire (or Pt plate) was used for a working, reference and counter electrode, respectively. The electrolysis was carried out under $50 \mathrm{~mL}$ of $20 \mathrm{mM}$ cobalt nitrate solution by applying $+1.3 \mathrm{~V}$ vs. NHE for $1 \mathrm{~h}$ without stirring. The $\mathrm{CoCaP}$ was prepared by the same way in the absence of rGO.

\subsection{Characterization}

The crystallinity of CoCaP/rGO film was determined by the X-ray diffraction (XRD, $3 \mathrm{~kW} \mathrm{Cu} \mathrm{X-ray} \mathrm{Diffractometer,} \mathrm{D8} \mathrm{Advance,} \mathrm{Bruker} \mathrm{AXS,} \mathrm{Hamburg,} \mathrm{Germany).} \mathrm{The}$ shape of analysis of the $\mathrm{CaP} / \mathrm{rGO}$ and $\mathrm{CoCaP} / \mathrm{rGO}$ was performed using a Field Emission Transmission Electron Microscope (FE-TEM, JEM-F200, JEOL, Tokyo, Japan) and Scanning Electron Microscopy (SEM, JSM-6700F, JEOL, Tokyo, Japan). The morphology of the sample was analyzed using a holey carbon grid to map the carbon elements for TEM-EDS measurements. The surface elemental analysis was characterized by X-ray Photoelectron Spectroscopy (XPS, ULVAC-PHI Inc. PHI 5000 Versaprobe, Chigasaki, Japan). Electrochemical measurements were performed by a three-electrode electrochemical cell system with commercial potentiostats (EC Epsilon, BASi and ZIVE SP1, Wonatech). Linear sweep voltammetry (LSV) was carried out at $5 \mathrm{mV} / \mathrm{s}$, and Tafel data were obtained from LSV. The electrochemical behavior of cyclic voltammetry was studied in $0.1 \mathrm{M}$ potassium phosphate buffer solution ( $\mathrm{pH} 7$ ) with a sweep rate of $10 \mathrm{mV} / \mathrm{s}$ without $\mathrm{iR}$ compensation. Both CV and LSV were performed using a glassy carbon electrode (GCE) of $5 \mathrm{~mm}$ in diameter as the working electrode. The electrochemical double-layer capacitance $\left(\mathrm{C}_{\mathrm{dl}}\right)$ was investigated using the $\mathrm{CV}$ method [72] in a potential range not affected by the faradaic current. All potentials were converted to the normal hydrogen electrode (NHE) using the following formula:

$$
\mathrm{E}(\mathrm{NHE})=\mathrm{E}(\mathrm{Ag} / \mathrm{AgCl})+0.197 \mathrm{~V}
$$

The overpotential for oxygen evolution was calculated using the following formula:

$$
\eta=\mathrm{E}(\mathrm{NHE})+0.059 \times \mathrm{pH}-1.23
$$




\section{Conclusions}

In summary, we prepared cobalt-calcium phosphate on reduced graphene oxide $(\mathrm{CoCaP} / \mathrm{rGO})$ by applying the anodic electrolysis in cobalt aqueous solution. During the anodic electrolysis process, the $\mathrm{CaP} / \mathrm{rGO}$ was electrochemically converted into an amorphous phase of $\mathrm{CoCaP} / \mathrm{rGO}$ and identified by XRD experiment. The TEM-EDS and XPS experiments of $\mathrm{CoCaP} / \mathrm{rGO}$ suggest that amorphous cobalt oxide/phosphates are well dispersed on rGO. Furthermore, bulk electrolysis of chronoamperometric measurements demonstrated the stability of catalysts under the neutral conditions. Comparing the catalytic activity between $\mathrm{CoCaP}$ and $\mathrm{CoCaP} / \mathrm{rGO}$, we conclude that the dispersion of $\mathrm{CoCaP}$ on rGO with high conductivity enhanced catalytic activities in neutral conditions.

Supplementary Materials: The following are available online at https:/ /www.mdpi.com/article/ 10.3390/catal11080960/s1: Figure S1: photographs taken in each step of the experiment; Figure S2: XRD patterns for $\mathrm{CaHPO}_{4}$ (monetite), $\mathrm{CaP} / \mathrm{rGO}$ and $\mathrm{CoCaP} / \mathrm{rGO}$ and Miller facets of the nine peaks of $\mathrm{CaHPO}_{4}$; Figure S3: TEM images and EDS elements mapping images of $\mathrm{CaP} / \mathrm{rGO}$; Figure S4: SEM images of $\mathrm{CaP} / \mathrm{rGO}, \mathrm{CoCaP} / \mathrm{rGO}$ and EDS elemental mapping images of $\mathrm{CoCaP} / \mathrm{rGO}$; Figure S5: XPS spectrum comparing before and after anodic electrolysis of $\mathrm{CaP} / \mathrm{rGO}$; Figure S6: cyclic voltammetry experiments of the current density of $\mathrm{CoCaP}$ and $\mathrm{CoCaP} / \mathrm{rGO}$ composite; Video S1: the anodic electrolysis of $\mathrm{CaP} / \mathrm{rGO}$ for $1 \mathrm{~h}$ in $20 \mathrm{mM} \mathrm{Co}^{2+}$ aqueous solution; Video S2: the surface of $\mathrm{CoCaP} / \mathrm{rGO}-$ coated ITO electrode at $1.5 \mathrm{~V}$ vs. NHE in $0.1 \mathrm{M} \mathrm{KPi} \mathrm{(pH} \mathrm{7);} \mathrm{Table} \mathrm{S1:} \mathrm{the} \mathrm{crystal} \mathrm{size} \mathrm{of} \mathrm{CaHPO}_{4}$ derived from XRD peaks using the Scherrer equation.

Author Contributions: K.-Y.K. and D.-K.L. conceived and designed the experiments; K.L. performed the syntheses of catalysts and the examination of catalytic properties; E.P., H.C. and Y.C. contributed to the scientific discussion; S.L. and C.S.K. contributed XRD and XPS experiments; W.Y. synthesized the reduced graphene oxide and contributed TEM-EDS experiments; K.-Y.K. and K.L. wrote the manuscript. All authors have read and agreed to the published version of the manuscript.

Funding: This work was supported by the Basic Science Research Program through the National Research Foundation of Korea (NRF), funded by the Ministry of Education (NRF-2019R111A3A0105983712, K.-Y.K.) and National Research Fund of Korea (2018R1A2A3075499, D.-K.L.).

Data Availability Statement: The data are contained within the article.

Conflicts of Interest: The authors declare no conflict of interest.

\section{References}

1. Lewis, N.S.; Nocera, D.G. Powering the planet: Chemical challenges in solar energy utilization. Proc. Natl. Acad. Sci. USA 2006, 103, 15729-15735. [CrossRef] [PubMed]

2. Kiwi, J.; Grätzel, M. Oxygen Evolution from Water via Redox Catalysis. Angew. Chem. Int. Ed. 1978, 17, 860-861. [CrossRef]

3. Galizzioli, D.; Tantardini, F.; Trasatti, S. Ruthenium dioxide: A new electrode material. I. Behaviour in acid solutions of inert electrolytes. J. Appl. Electrochem. 1974, 4, 57-67. [CrossRef]

4. Lee, Y.; Suntivich, J.; May, K.J.; Perry, E.E.; Shao-Horn, Y. Synthesis and activities of rutile $\mathrm{IrO}_{2}$ and $\mathrm{RuO}_{2}$ nanoparticles for oxygen evolution in acid and alkaline solutions. J. Phys. Chem. Lett. 2012, 3, 399-404. [CrossRef] [PubMed]

5. Reier, T.; Oezaslan, M.; Strasser, P. Electrocatalytic oxygen evolution reaction (OER) on Ru, Ir, and Pt catalysts: A comparative study of nanoparticles and bulk materials. ACS Catal. 2012, 2, 1765-1772. [CrossRef]

6. Cherevko, S.; Geiger, S.; Kasian, O.; Kulyk, N.; Grote, J.P.; Savan, A.; Shrestha, B.R.; Merzlikin, S.; Breitbach, B.; Ludwig, A.; et al. Oxygen and hydrogen evolution reactions on $\mathrm{Ru}, \mathrm{RuO}_{2}$, Ir, and $\mathrm{IrO}_{2}$ thin film electrodes in acidic and alkaline electrolytes: A comparative study on activity and stability. Catal. Today 2016, 262, 170-180. [CrossRef]

7. Gray, H.B. Powering the planet with solar fuel. Nat. Chem. 2009, 1, 7. [CrossRef]

8. Yang, Y.; Fei, H.; Ruan, G.; Tour, J.M. Porous cobalt-based thin film as a bifunctional catalyst for hydrogen generation and oxygen generation. Adv. Mater. 2015, 27, 3175-3180. [CrossRef]

9. Jin, H.; Wang, J.; Su, D.; Wei, Z.; Pang, Z.; Wang, Y. In Situ Cobalt-Cobalt Oxide/N-Doped Carbon Hybrids as Superior Bifunctional Electrocatalysts for Hydrogen and Oxygen Evolution. J. Am. Chem. Soc. 2015, 137, 2688-2694. [CrossRef]

10. Dou, S.; Tao, L.; Huo, J.; Wang, S.; Dai, L. Etched and doped $\mathrm{Co}_{9} \mathrm{~S}_{8} /$ graphene hybrid for oxygen electrocatalysis. Energy Environ. Sci. 2016, 9, 1320-1326. [CrossRef]

11. Qiao, X.; Jin, J.; Fan, H.; Cui, L.; Ji, S.; Li, Y.; Liao, S. Cobalt and Nitrogen Co-Doped Graphene-Carbon Nanotube Aerogel as an Efficient Bifunctional Electrocatalyst for Oxygen Reduction and Evolution Reactions. Catalysts 2018, 8, 275. [CrossRef] 
12. Ahsan, M.A.; Puente Santiago, A.R.; Hong, Y.; Zhang, N.; Cano, M.; Rodriguez-Castellon, E.; Echegoyen, L.; Sreenivasan, S.T.; Noveron, J.C. Tuning of Trifunctional NiCu Bimetallic Nanoparticles Confined in a Porous Carbon Network with Surface Composition and Local Structural Distortions for the Electrocatalytic Oxygen Reduction, Oxygen and Hydrogen Evolution Reactions. J. Am. Chem. Soc. 2020, 142, 14688-14701. [CrossRef] [PubMed]

13. Li, J.S.; Li, S.L.; Tang, Y.J.; Han, M.; Dai, Z.H.; Bao, J.C.; Lan, Y.Q. Nitrogen-doped Fe/Fe $\mathrm{C}_{3} @$ graphitic layer/carbon nanotube hybrids derived from MOFs: Efficient bifunctional electrocatalysts for ORR and OER. Chem. Commun. 2015, 51, $2710-2713$. [CrossRef] [PubMed]

14. Wang, Q.; Lei, Y.; Chen, Z.; Wu, N.; Wang, Y.; Wang, B.; Wang, Y. Fe/Fe 3 C@C nanoparticles encapsulated in N-doped graphene$\mathrm{CNTs}$ framework as an efficient bifunctional oxygen electrocatalyst for robust rechargeable Zn-air batteries. J. Mater. Chem. A 2018, 6, 516-526. [CrossRef]

15. Jia, Y.; Zhang, L.; Gao, G.; Chen, H.; Wang, B.; Zhou, J.; Soo, M.T.; Hong, M.; Yan, X.; Qian, G.; et al. A Heterostructure Coupling of Exfoliated Ni-Fe Hydroxide Nanosheet and Defective Graphene as a Bifunctional Electrocatalyst for Overall Water Splitting. Adv. Mater. 2017, 29, 1700017. [CrossRef]

16. Yu, X.; Zhang, M.; Yuan, W.; Shi, G. A high-performance three-dimensional Ni-Fe layered double hydroxide/graphene electrode for water oxidation. J. Mater. Chem. A 2015, 3, 6921-6928. [CrossRef]

17. Bao, J.; Xie, J.; Lei, F.; Wang, Z.; Liu, W.; Xu, L.; Guan, M.; Zhao, Y.; Li, H. Two-Dimensional Mn-Co LDH/Graphene Composite towards High-Performance Water Splitting. Catalysts 2018, 8, 350. [CrossRef]

18. Liu, Y.; Jiang, H.; Zhu, Y.; Yang, X.; Li, C. Transition metals (Fe, Co, and Ni) encapsulated in nitrogen-doped carbon nanotubes as bi-functional catalysts for oxygen electrode reactions. J. Mater. Chem. A 2016, 4, 1694-1701. [CrossRef]

19. Yan, W.; Bian, W.; Jin, C.; Tian, J.-H.; Yang, R. An Efficient Bi-functional Electrocatalyst Based on Strongly Coupled CoFe2O4/Carbon Nanotubes Hybrid for Oxygen Reduction and Oxygen Evolution. Electrochim. Acta 2015, 177, 65-72. [CrossRef]

20. Zhang, X.; Xu, H.; Li, X.; Li, Y.; Yang, T.; Liang, Y. Facile Synthesis of Nickel-Iron/Nanocarbon Hybrids as Advanced Electrocatalysts for Efficient Water Splitting. ACS Catal. 2016, 6, 580-588. [CrossRef]

21. Mao, S.; Pu, H.; Chen, J. Graphene oxide and its reduction: Modeling and experimental progress. RSC Adv. 2012, 2, 2643-2662. [CrossRef]

22. Dreyer, D.R.; Park, S.; Bielawski, C.W.; Ruoff, R.S. The chemistry of graphene oxide. Chem. Soc. Rev. 2010, 39, 228-240. [CrossRef]

23. Zhu, Y.; Murali, S.; Cai, W.; Li, X.; Suk, J.W.; Potts, J.R.; Ruoff, R.S. Graphene and graphene oxide: Synthesis, properties, and applications. Adv. Mater. 2010, 22, 3906-3924. [CrossRef] [PubMed]

24. Park, S.; Ruoff, R.S. Chemical methods for the production of graphenes. Nat. Nanotechnol. 2009, 4, 217-224. [CrossRef]

25. Liang, Y.; Li, Y.; Wang, H.; Zhou, J.; Wang, J.; Regier, T.; Dai, H. $\mathrm{Co}_{3} \mathrm{O}_{4}$ nanocrystals on graphene as a synergistic catalyst for oxygen reduction reaction. Nat. Mater. 2011, 10, 780-786. [CrossRef]

26. Mao, S.; Wen, Z.; Huang, T.; Hou, Y.; Chen, J. High-performance bi-functional electrocatalysts of 3D crumpled graphene-cobalt oxide nanohybrids for oxygen reduction and evolution reactions. Energy Environ. Sci. 2014, 7, 609-616. [CrossRef]

27. Long, X.; Li, J.; Xiao, S.; Yan, K.; Wang, Z.; Chen, H.; Yang, S. A strongly coupled graphene and FeNi double hydroxide hybrid as an excellent electrocatalyst for the oxygen evolution reaction. Angew. Chem. Int. Ed. 2014, 53, 7584-7588. [CrossRef]

28. Liu, Q.; Jin, J.; Zhang, J. NiCo2S4@graphene as a bifunctional electrocatalyst for oxygen reduction and evolution reactions. ACS Appl. Mater. Interfaces 2013, 5, 5002-5008. [CrossRef]

29. Jahan, M.; Liu, Z.; Loh, K.P. A graphene oxide and copper-centered metal organic framework composite as a tri-functional catalyst for HER, OER, and ORR. Adv. Funct. Mater. 2013, 23, 5363-5372. [CrossRef]

30. Kanan, M.W.; Nocera, D.G. In situ formation of an oxygen-evolving catalyst in neutral water containing phosphate and Co ${ }^{2+}$. Science 2008, 321, 1072-1075. [CrossRef] [PubMed]

31. Surendranath, Y.; Kanan, M.W.; Nocera, D.G. Mechanistic studies of the oxygen evolution reaction by a cobalt-phosphate catalyst at neutral pH. J. Am. Chem. Soc. 2010, 132, 16501-16509. [CrossRef]

32. Esswein, A.J.; Surendranath, Y.; Reece, S.Y.; Nocera, D.G. Highly active cobalt phosphate and borate based oxygen evolving catalysts operating in neutral and natural waters. Energy Environ. Sci. 2011, 4, 499-504. [CrossRef]

33. Kanan, M.W.; Yano, J.; Surendranath, Y.; Dincǎ, M.; Yachandra, V.K.; Nocera, D.G. Structure and valency of a cobalt-phosphate water oxidation catalyst determined by in situ X-ray spectroscopy. J. Am. Chem. Soc. 2010, 132, 13692-13701. [CrossRef]

34. Kanan, M.W.; Surendranath, Y.; Nocera, D.G. Cobalt-phosphate oxygen-evolving compound. Chem. Soc. Rev. 2009, 38, 109-114. [CrossRef]

35. Surendranath, Y.; Dincǎ, M.; Nocera, D.G. Electrolyte-Dependent Electrosynthesis and Activity of Cobalt-Based Water Oxidation Catalysts. J. Am. Chem. Soc. 2009, 131, 2615-2620. [CrossRef] [PubMed]

36. Brodsky, C.N.; Bediako, D.K.; Shi, C.; Keane, T.P.; Costentin, C.; Billinge, S.J.L.; Nocera, D.G. Proton-Electron Conductivity in Thin Films of a Cobalt-Oxygen Evolving Catalyst. ACS Appl. Energy Mater. 2019, 2, 3-12. [CrossRef]

37. Xie, L.; Zhang, R.; Cui, L.; Liu, D.; Hao, S.; Ma, Y.; Du, G.; Asiri, A.M.; Sun, X. High-Performance Electrolytic Oxygen Evolution in Neutral Media Catalyzed by a Cobalt Phosphate Nanoarray. Angew. Chem. Int. Ed. 2017, 56, 1064-1068. [CrossRef]

38. Pyo, E.; Lee, K.; Jang, M.J.; Ko, I.H.; Kim, C.S.; Choi, S.M.; Lee, S.; Kwon, K.Y. Cobalt Incorporated Hydroxyapatite Catalyst for Water Oxidation. ChemCatChem 2019, 11, 5425-5429. [CrossRef]

39. Jaworski, J.W.; Cho, S.; Kim, Y.; Jung, J.H.; Jeon, H.S.; Min, B.K.; Kwon, K.Y. Hydroxyapatite supported cobalt catalysts for hydrogen generation. J. Colloid Interface Sci. 2013, 394, 401-408. [CrossRef] 
40. Han, A.; Wu, H.; Sun, Z.; Jia, H.; Yan, Z.; Ma, H.; Liu, X.; Du, P. Green Cobalt Oxide (CoOx) Film with Nanoribbon Structures Electrodeposited from the BF2-Annulated Cobaloxime Precursor for Efficient Water Oxidation. ACS Appl. Mater. Interfaces 2014, 6, 10929-10934. [CrossRef] [PubMed]

41. Tian, J.; Li, H.; Asiri, A.M.; Al-Youbi, A.O.; Sun, X. Photoassisted Preparation of Cobalt Phosphate/Graphene Oxide Composites: A Novel Oxygen-Evolving Catalyst with High Efficiency. Small 2013, 9, 2709-2714. [CrossRef]

42. Han, A.; Wu, H.; Sun, Z.; Jia, H.; Du, P. Facile deposition of nanostructured cobalt oxide catalysts from molecular cobaloximes for efficient water oxidation. Phys. Chem. Chem. Phys. 2013, 15, 12534-12538. [CrossRef] [PubMed]

43. González-Flores, D.; Sánchez, I.; Zaharieva, I.; Klingan, K.; Heidkamp, J.; Chernev, P.; Menezes, P.W.; Driess, M.; Dau, H.; Montero, M.L. Heterogeneous Water Oxidation: Surface Activity versus Amorphization Activation in Cobalt Phosphate Catalysts. Angew. Chem. Int. Ed. 2015, 54, 2472-2476. [CrossRef]

44. Menezes, P.W.; Panda, C.; Walter, C.; Schwarze, M.; Driess, M. A Cobalt-Based Amorphous Bifunctional Electrocatalysts for Water-Splitting Evolved from a Single-Source Lazulite Cobalt Phosphate. Adv. Funct. Mater. 2019, 29, 1808632. [CrossRef]

45. Kim, D.; Lee, S.; Woo, D.; Byun, J.; Kwon, K. Synthesis and Morphological Characterization of Calcium Phosphates Prepared under Different NaOH Concentrations. Bull. Korean Chem. Soc. 2014, 35, 2241-2242. [CrossRef]

46. Liu, Y.; Nocera, D.G. Spectroscopic Studies of Nanoparticulate Thin Films of a Cobalt-Based Oxygen Evolution Catalyst. J. Phys. Chem. C 2014, 118, 17060-17066. [CrossRef]

47. Ryu, J.; Jung, N.; Jang, J.H.; Kim, H.-J.; Yoo, S.J. In Situ Transformation of Hydrogen-Evolving CoP Nanoparticles: Toward Efficient Oxygen Evolution Catalysts Bearing Dispersed Morphologies with Co-oxo/hydroxo Molecular Units. ACS Catal. 2015, 5, 4066-4074. [CrossRef]

48. Chusuei, C.C.; Goodman, D.W.; Van Stipdonk, M.J.; Justes, D.R.; Schweikert, E.A. Calcium Phosphate Phase Identification Using XPS and Time-of-Flight Cluster SIMS. Anal. Chem. 1999, 71, 149-153. [CrossRef]

49. Lu, H.B.; Campbell, C.T.; Graham, D.J.; Ratner, B.D. Surface Characterization of Hydroxyapatite and Related Calcium Phosphates by XPS and TOF-SIMS. Anal. Chem. 2000, 72, 2886-2894. [CrossRef]

50. Ahn, H.S.; Tilley, T.D. Electrocatalytic Water Oxidation at Neutral pH by a Nanostructured $\mathrm{Co}\left(\mathrm{PO}_{3}\right)_{2}$ Anode. Adv. Funct. Mater. 2013, 23, 227-233. [CrossRef]

51. Burke, M.S.; Zou, S.; Enman, L.J.; Kellon, J.E.; Gabor, C.A.; Pledger, E.; Boettcher, S.W. Revised Oxygen Evolution Reaction Activity Trends for First-Row Transition-Metal (Oxy)hydroxides in Alkaline Media. J. Phys. Chem. Lett. 2015, 6, 3737-3742. [CrossRef]

52. Han, B.; Qian, D.; Risch, M.; Chen, H.; Chi, M.; Meng, Y.S.; Shao-Horn, Y. Role of $\mathrm{LiCoO}_{2}$ Surface Terminations in Oxygen Reduction and Evolution Kinetics. J. Phys. Chem. Lett. 2015, 6, 1357-1362. [CrossRef]

53. Yang, L.; Lv, Y.; Cao, D. Co,N-codoped nanotube/graphene 1D/2D heterostructure for efficient oxygen reduction and hydrogen evolution reactions. J. Mater. Chem. A 2018, 6, 3926-3932. [CrossRef]

54. Liu, X.; Liu, W.; Ko, M.; Park, M.; Kim, M.G.; Oh, P.; Chae, S.; Park, S.; Casimir, A.; Wu, G.; et al. Metal (Ni, Co)-Metal Oxides/Graphene Nanocomposites as Multifunctional Electrocatalysts. Adv. Funct. Mater. 2015, 25, 5799-5808. [CrossRef]

55. Li, Y.; Wang, H.; Xie, L.; Liang, Y.; Hong, G.; Dai, H. MoS2 Nanoparticles Grown on Graphene: An Advanced Catalyst for the Hydrogen Evolution Reaction. J. Am. Chem. Soc. 2011, 133, 7296-7299. [CrossRef]

56. Ge, R.; Du, H.; Tao, K.; Zhang, Q.; Chen, L. Cobalt-Borate Nanoarray: An Efficient and Durable Electrocatalyst for Water Oxidation under Benign Conditions. ACS Appl. Mater. Interfaces 2017, 9, 15383-15387. [CrossRef]

57. Aksoy, M.; Nune, S.V.K.; Karadas, F. A Novel Synthetic Route for the Preparation of an Amorphous Co/Fe Prussian Blue Coordination Compound with High Electrocatalytic Water Oxidation Activity. Inorg. Chem. 2016, 55, 4301-4307. [CrossRef]

58. Pintado, S.; Goberna-Ferrón, S.; Escudero-Adán, E.C.; Galán-Mascarós, J.R. Fast and Persistent Electrocatalytic Water Oxidation by Co-Fe Prussian Blue Coordination Polymers. J. Am. Chem. Soc. 2013, 135, 13270-13273. [CrossRef] [PubMed]

59. Li, K.; Zhang, J.; Wu, R.; Yu, Y.; Zhang, B. Anchoring CoO Domains on CoSe2 Nanobelts as Bifunctional Electrocatalysts for Overall Water Splitting in Neutral Media. Adv. Sci. 2016, 3, 1500426. [CrossRef]

60. Chen, S.; Duan, J.; Jaroniec, M.; Qiao, S.Z. Three-Dimensional N-Doped Graphene Hydrogel/NiCo Double Hydroxide Electrocatalysts for Highly Efficient Oxygen Evolution. Angew. Chem. Int. Ed. 2013, 52, 13567-13570. [CrossRef]

61. Bian, W.; Yang, Z.; Strasser, P.; Yang, R. A CoFe ${ }_{2} \mathrm{O}_{4}$ /graphene nanohybrid as an efficient bi-functional electrocatalyst for oxygen reduction and oxygen evolution. J. Power Sources 2014, 250, 196-203. [CrossRef]

62. Zhao, Y.; Chen, S.; Sun, B.; Su, D.; Huang, X.; Liu, H.; Yan, Y.; Sun, K.; Wang, G. Graphene- $\mathrm{Co}_{3} \mathrm{O}_{4}$ nanocomposite as electrocatalyst with high performance for oxygen evolution reaction. Sci. Rep. 2015, 5, 7629. [CrossRef] [PubMed]

63. Chen, P.; Xu, K.; Zhou, T.; Tong, Y.; Wu, J.; Cheng, H.; Lu, X.; Ding, H.; Wu, C.; Xie, Y. Strong-Coupled Cobalt Borate Nanosheets/Graphene Hybrid as Electrocatalyst for Water Oxidation Under Both Alkaline and Neutral Conditions. Angew. Chem. Int. Ed. 2016, 55, 2488-2492. [CrossRef] [PubMed]

64. Li, Y.; Zhao, Y.; Zhang, Z. A porous graphene/cobalt phosphate composite as an efficient oxygen evolving catalyst. Electrochem. Commun. 2014, 48, 35-39. [CrossRef]

65. Mao, S.; Wen, Z.; Kim, H.; Lu, G.; Hurley, P.; Chen, J. A General Approach to One-Pot Fabrication of Crumpled Graphene-Based Nanohybrids for Energy Applications. ACS Nano 2012, 6, 7505-7513. [CrossRef] [PubMed]

66. Li, D.; Müller, M.B.; Gilje, S.; Kaner, R.B.; Wallace, G.G. Processable aqueous dispersions of graphene nanosheets. Nat. Nanotechnol. 2008, 3, 101-105. [CrossRef] [PubMed] 
67. Lim, D.-K.; Barhoumi, A.; Wylie, R.G.; Reznor, G.; Langer, R.S.; Kohane, D.S. Enhanced Photothermal Effect of Plasmonic Nanoparticles Coated with Reduced Graphene Oxide. Nano Lett. 2013, 13, 4075-4079. [CrossRef] [PubMed]

68. Moon, H.; Kumar, D.; Kim, H.; Sim, C.; Chang, J.-H.; Kim, J.-M.; Kim, H.; Lim, D.-K. Amplified Photoacoustic Performance and Enhanced Photothermal Stability of Reduced Graphene Oxide Coated Gold Nanorods for Sensitive Photoacoustic Imaging. ACS Nano 2015, 9, 2711-2719. [CrossRef]

69. Kumar, D.; Lee, A.; Lee, T.; Lim, M.; Lim, D.-K. Ultrafast and Efficient Transport of Hot Plasmonic Electrons by Graphene for Pt Free, Highly Efficient Visible-Light Responsive Photocatalyst. Nano Lett. 2016, 16, 1760-1767. [CrossRef] [PubMed]

70. Tamimi, F.; Sheikh, Z.; Barralet, J. Dicalcium phosphate cements: Brushite and monetite. Acta Biomater. 2012, 8, 474-487. [CrossRef]

71. Fuller, T.F.; Newman, J. Experimental Determination of the Transport Number of Water in Nafion 117 Membrane. J. Electrochem. Soc. 1992, 139, 1332-1337. [CrossRef]

72. Anantharaj, S.; Ede, S.R.; Karthick, K.; Sam Sankar, S.; Sangeetha, K.; Karthik, P.E.; Kundu, S. Precision and correctness in the evaluation of electrocatalytic water splitting: Revisiting activity parameters with a critical assessment. Energy Environ. Sci. 2018, 11, 744-771. [CrossRef] 